\title{
Maternal and perinatal outcome in patients of preeclampsia with and without HELLP syndrome
}

\author{
Hritul Madge*, Sunita Seth
}

Department of Obstetrics and Gynecology, Deen Dayal Upadhyay Hospital, New Delhi, India

Received: 13 March 2019

Accepted: 09 April 2019

*Correspondence:

Dr. Hritul Madge,

E-mail: drhritulmadge@gmail.com

Copyright: () the author(s), publisher and licensee Medip Academy. This is an open-access article distributed under the terms of the Creative Commons Attribution Non-Commercial License, which permits unrestricted non-commercial use, distribution, and reproduction in any medium, provided the original work is properly cited.

\begin{abstract}
Background: Preeclampsia is seen in about 5-10\% of all pregnancies and HELLP Syndrome occurs in $6-12 \%$ of these patients. Both are known to increase maternal and perinatal morbidity. The study aims to provide a comprehensive view of these myriad outcomes in the mother and neonate both, in each of the groups. It also compares the incidence of such outcomes in mother and child, in preeclampsia only and in those complicated by HELLP syndrome.

Methods: This prospective, observational, comparative study was conducted at a tertiary referral centre. 55 patients with preeclampsia were compared with 55 patients with HELLP syndrome. The relevant clinical features, laboratory investigations and the maternal and perinatal outcomes along with the incidence were studied and results analyzed.

Results: Significant differences were observed in laboratory parameters and duration of ICU stay in patients with preeclampsia and patients with HELLP syndrome. Incidence of maternal complications and need for blood transfusion was greater in HELLP syndrome. Only marginal differences were observed in birth weight, NICU admission rates and neonatal mortality rates.

Conclusions: HELLP syndrome is associated with increased maternal morbidity and mortality as compared to preeclampsia. Neonatal outcomes appear to be influenced; only marginally, by HELLP syndrome, nevertheless, their incidence is more than in preeclampsia. Aggressive treatment for pregnant women appears to decrease the maternal mortality rate.
\end{abstract}

Keywords: HELLP syndrome, Maternal and perinatal outcome, Preeclampsia

\section{INTRODUCTION}

Preeclampsia complicates $5-10 \%$ of all pregnancies. ${ }^{1}$ HELLP syndrome develops in $6-12 \%$ of women with preeclampsia or eclampsia, accounting for $0.4-0.7 \%$ of all pregnancies. $^{2}$

The acronym HELLP was coined by Louis Weinstein in 1982. ${ }^{3}$ It is characterised by H- hemolysis, EL- elevated liver enzymes and LP- low platelet count. It is a placentainstigated, liver targeted acute inflammatory disorder with elements of disordered immunological processes. Like severe preeclampsia it develops from aberrant development, function and ischemia of the placenta resulting in a cascade of derangements and dysfunctions that is terminated only by delivery.

Early diagnosis is critical as it is not only associated with maternal morbidity and mortality, but the frequency of these complications is also high. Perinatal mortality appears to be primarily related to the gestational age at the time of delivery.

High maternal and perinatal morbidity is due to under diagnosis and delayed treatment of preeclampsia. Developed nations have achieved great success in 
combating it and research activities are now focused on early predictors to facilitate early diagnosis, prevention and management but developing nations have a long way to go.

The purpose of the study is to appraise ourselves with the maternal and perinatal outcome as well as the complications occurring in patients with preeclapmsia without HELLP Syndrome and patients with HELLP Syndrome separately. It also aims to assess the incidence of such outcomes and complications in each group.

\section{METHODS}

This prospective, observational, comparative study was conducted at a tertiary care centre over a period of 2 years. After obtaining ethical approval, patients with preeclampsia presenting to the gynaecology emergency unit were studied and were divided into group $\mathrm{A}$ and group B.

Group A comprised of 55 patients with preeclampsia with HELLP syndrome with one or more of the following:

- Hemolysis detected by either progressive anemia, elevated bilirubin or elevated LDH levels.

- Elevated liver enzymes.

a) Serum lactate dehydrogenase $(\mathrm{LDH})>600 \mathrm{IU} / \mathrm{L}$

b) Serum aspartate aminotransferase $(\mathrm{AST})>40 \mathrm{IU} / \mathrm{L}$

c) Serum alanine aminotransferase (ALT) $>40 \mathrm{IU} / \mathrm{L}$

- Low Platelet count $<1,00,000 / \mu \mathrm{L} 4$

Group B comprised of 55 patients with preeclampsia without HELLP syndrome:

- Blood pressure:

d) Systolic greater than or equal to $140 \mathrm{~mm} \mathrm{Hg}$

e) Diastolic greater than $90 \mathrm{~mm} \mathrm{Hg}$

- Proteinuria: Greater than or equal to $300 \mathrm{mg} / 24 \mathrm{hrs}$ or greater than or equal to $30 \mathrm{mg} / \mathrm{dL}(1+)$ persistent 4

- Serum transaminase normal at the time of admission.

Patients with preexisting hypertension, known cases of hepatic disease, hemolytic anemias, platelet disorders, chronic renal disorders, diabetes mellitus, thyroid disorders, heart disease, pulmonary disease as well as pregnancies with multiple gestation, prolonged leaking per vaginum and placenta previa were excluded from the study.

Following parameters were assessed: maternal age, parity, booking status, gestational age, systolic and diastolic blood pressures, clinical features, laboratory parameters like blood group and $\mathrm{Rh}$ typing, complete blood count, peripheral smear, bleeding time, clotting time, prothrombin time, International Normalised Ratio (INR), renal function tests, liver function tests, urine routine and 24 hours urine proteins, fundoscopy, blood sugar; maternal complications, ICU stay, mode of delivery, blood and blood products transfused, maternal death and causes of death, perinatal outcome neonatal complications, NICU stay, neonatal death and causes of neonatal death.

\section{Statistical Analysis}

Statistical testing was conducted with the statistical package for social science system version SPSS 17.0. Continuous variables were presented as mean (SD) or median if the data is unevenly distributed. Categorical variables were expressed as frequencies and percentages. The comparison of normally distributed continuous variables between the groups was performed using student $\mathrm{t}$ test.

Nominal categorical data between the groups was compared using Chi-square test or Fischer's exact test as appropriate. Non-normal distribution continuous variables were compared using Mann Whitney U test. For all statistical tests, a $\mathrm{p}$ value less than 0.05 was taken to indicate a significant difference.

\section{RESULTS}

There were 55 patients of preeclampsia and 55 patients of HELLP syndrome were assessed for various demographic, clinical and biochemical parameters.

\section{Demographic parameters}

\section{Distribution of cases according to parity}

In the present study, in both the groups, 17 patients were primigravida, 21 were second gravida and 2 were 5 th gravida.

In HELLP syndrome group 11 were $3^{\text {rd }}$ gravid and 4 were 4 th gravid. In preeclampsia group, 10 patients were 3 rd gravid and 6 were 4th gravida.

\section{Age wise distribution of cases}

In the present study, maximum number of patients were in age group 21-25 years in both preeclampsia and HELLP syndrome group i.e. $30 \%$ in preeclampsia group and $32.7 \%$ in HELLP syndrome group. $21.8 \%$ patients were between $16-20$ years, $31 \%$ belonged to $26-30$ age group, $26.4 \%$ belonged to $31-40$ age group and $0.018 \%$ belonged to $41-45$ age group.

\section{Distribution of cases according to gestational age}

In the present study $33.64 \%$ patients were under 34 weeks of gestation and $66.36 \%$ patients were above 34 weeks of gestation.

The mean gestational age was 36.57 weeks. Mean gestational age for preeclampsia group was 35.83 weeks and that for HELLP group was 36.77 weeks. 
Table 1: Distribution of cases according to gestational age.

\begin{tabular}{|llll|}
\hline Gestational age & PE & HELLP & Total \\
\hline$<34$ Weeks & $14(25.45 \%)$ & $11(20 \%)$ & $37(33.64 \%)$ \\
\hline$>34$ Weeks & $41(74.55 \%)$ & $44(80 \%)$ & $73(66.36 \%)$ \\
\hline
\end{tabular}

\section{Maternal outcome}

\section{Blood pressure}

Mean systolic BP was $153 \mathrm{mmHg}$ and $154 \mathrm{mmHg}$ and diastolic BP was $102 \mathrm{mmHg}$ and $98 \mathrm{mmHg}$ in preeclampsia and HELLP groups respectively. Majority of patients in both the groups had systolic BP in the range of 140-159 mmHg. Diastolic BP was in the lower limits of hypertension in patients with HELLP syndrome- 90-99 $\mathrm{mmHg}$.

\section{Clinical features}

Clinical features of impending eclampsia - headache, blurring of vision and epigastric pain were commonly reported by HELLP syndrome patients. Headache was the most common symptom reported by patients in both the groups, $52.72 \%$ in HELLP group and $29.09 \%$ in preeclampsia group.

Table 2: Frequency of clinical features in PE and HELLP patients.

\begin{tabular}{|lll|}
\hline $\begin{array}{l}\text { Clinical } \\
\text { features }\end{array}$ & $\begin{array}{l}\text { PE (no. of pts) } \\
\text { (Percentage) }\end{array}$ & $\begin{array}{l}\text { HELLP (no. of } \\
\text { pts) (Percentage) }\end{array}$ \\
\hline Headache & $16(29.09)$ & $29(52.72)$ \\
\hline $\begin{array}{l}\text { Blurring of } \\
\text { vision }\end{array}$ & $3(0.05)$ & $7(0.12)$ \\
\hline $\begin{array}{l}\text { Epigastric } \\
\text { pain }\end{array}$ & $2(0.04)$ & $14(0.25)$ \\
\hline
\end{tabular}

\section{Eclampsia}

Incidence of eclampsia was double in HELLP group$18.18 \%$ as compared to preeclampsia group- $9.01 \%$.

Table 3: Frequency of Eclampsia in PE and HELLP patients.

\begin{tabular}{|llll|}
\hline $\begin{array}{l}\text { Incidence of } \\
\text { Eclampsia }\end{array}$ & $\begin{array}{l}\text { PE (no. } \\
\text { of pts) }\end{array}$ & $\begin{array}{l}\text { HELLP } \\
\text { (no. of pts) }\end{array}$ & $\begin{array}{l}\text { Total (no. } \\
\text { of pts) }\end{array}$ \\
\hline Occurred & $5(9.1)$ & $10(18.18)$ & $15(13.6)$ \\
\hline Not occurred & $\begin{array}{l}50 \\
(90.90)\end{array}$ & $45(81.82)$ & $95(86.4)$ \\
\hline
\end{tabular}

Mode of delivery

There was a significant difference observed in the mode of delivery. Patients with HELLP syndrome were more likely to undergo vaginal delivery.
26 patients with preeclampsia underwent LSCS while 10 in HELLP syndrome had caesarean. Vaginal delivery was seen more in HELLP group- 45 vs 29 patients in preeclampsia group.

Table 4: Mode of delivery in PE and HELLP patients.

\begin{tabular}{|c|c|c|c|c|}
\hline $\begin{array}{l}\text { Mode of } \\
\text { delivery }\end{array}$ & PE & HELLP & Total & $\begin{array}{l}p \\
\text { value }\end{array}$ \\
\hline LSCS & $\begin{array}{l}26 \\
(47.27 \%)\end{array}$ & $\begin{array}{l}10 \\
(18.19 \%)\end{array}$ & $\begin{array}{l}36 \\
(32.72 \%)\end{array}$ & \multirow{2}{*}{$\begin{array}{l}0.00 \\
1\end{array}$} \\
\hline Vaginal & $\begin{array}{l}29 \\
(52.72 \%)\end{array}$ & $\begin{array}{l}45 \\
(81.81 \%)\end{array}$ & $\begin{array}{l}74 \\
(67.27 \%)\end{array}$ & \\
\hline
\end{tabular}

\section{Maternal complications}

Maternal complications were more in HELLP group$40 \%$ vs $14.5 \%$ in preeclampsia group. Abruption was the most common maternal complication followed by DIC in both the groups (abruption-12.7\% and 5.45\%; DIC$10.9 \%$ and $3.63 \%$ )

Table 5: Frequency of maternal complications in PE and HELLP patients.

\begin{tabular}{|lll|}
\hline Complications & PE & HELLP \\
\hline None & 47 & 33 \\
\hline Abruption & 3 & 7 \\
\hline Pulmonary Edema & 1 & 6 \\
\hline DIC & 2 & 5 \\
\hline Renal Failure & 1 & 3 \\
\hline Sepsis & 1 & 2 \\
\hline Retinopathy & 1 & 0 \\
\hline Liver Hematoma & 0 & 2 \\
\hline
\end{tabular}

Blood transfusion

$70.9 \%$ patients in HELLP group needed blood transfusion whereas in preeclampsia group it was only $9.09 \%$.

\section{ICU Stay}

Admission rate to ICU was more in HELLP syndrome$34.55 \%$ than in preeclampsia group $9.1 \%$.

Table 6: Causes of maternal mortality in PE and HELLP patients.

\begin{tabular}{|ll|}
\hline HELLP & Percentage \\
\hline No mortality & 94.54 \\
\hline DIC & 3.63 \\
\hline Pulmonary Edema & 1.81 \\
\hline Renal failure & 1.81 \\
\hline PE & Percentage \\
\hline No mortality & 98.18 \\
\hline Renal failure & 1.81 \\
\hline DIC & 1.81 \\
\hline
\end{tabular}




\section{Mortality}

Maternal mortality was more in HELLP group- $5.45 \%$ than in preeclampsia group $1.8 \%$

\section{Neonatal outcome}

Birth weight

Birth weight was marginally low in HELLP group$1.76 \mathrm{~kg}$ than in preeclampsia $2 \mathrm{~kg}$.

Table 7: Distribution of cases according to birth weight of babies of PE and HELLP patients.

\begin{tabular}{|c|c|c|c|c|}
\hline $\begin{array}{l}\text { BABYWT } \\
\text { Category }\end{array}$ & $\begin{array}{l}\text { PE } \\
(\%)\end{array}$ & $\begin{array}{l}\text { HELLP } \\
(\%)\end{array}$ & $\begin{array}{l}\text { Total } \\
(\%)\end{array}$ & p value \\
\hline$<1.5 \mathrm{~kg}$ & $\begin{array}{l}8 \\
(14.5)\end{array}$ & $\begin{array}{l}11 \\
(20)\end{array}$ & $\begin{array}{l}19 \\
(17.3)\end{array}$ & \multirow{3}{*}{0.043} \\
\hline $1.5-2 \mathrm{~kg}$ & $\begin{array}{l}38 \\
(69.1)\end{array}$ & $\begin{array}{l}32 \\
(58.2)\end{array}$ & $\begin{array}{l}70 \\
(63.6)\end{array}$ & \\
\hline$>2.5 \mathrm{~kg}$ & $\begin{array}{l}9 \\
(16.4)\end{array}$ & $\begin{array}{l}12 \\
(21.8)\end{array}$ & $\begin{array}{l}21 \\
(19.1)\end{array}$ & \\
\hline
\end{tabular}

\section{Neonatal complications}

ARDS was the most common neonatal complication in both the groups, $29.09 \%$ in HELLP group and $12.72 \%$ in preeclampsia group.

Table 8: Frequency of neonatal complications in PE and HELLP patients.

\begin{tabular}{|lll|}
\hline HELLP & Frequency & Percentage \\
\hline None & 28 & 50.10 \\
\hline Prematurity & 18 & 32.72 \\
\hline ARDS & 16 & 29.09 \\
\hline IUD & 4 & 7.27 \\
\hline IUGR & 4 & 7.27 \\
\hline PE & Frequency & Percentage \\
\hline None & 33 & 60.00 \\
\hline Prematurity & 15 & 27.27 \\
\hline ARDS & 7 & 12.72 \\
\hline IUGR & 7 & 12.72 \\
\hline IUD & 2 & 3.63 \\
\hline Sepsis & 1 & 1.81 \\
\hline
\end{tabular}

\section{NICU Stay}

Both the groups had comparable rates of admission to NICU with marginal high incidence in HELLP group$32.72 \%$ vs $30.9 \%$ in preeclampsia.

\section{Mortality}

In both the groups, neonatal death was comparable, with marginally higher incidence in HELLP group than in preeclampsia $(15.38 \%$ vs $13.2 \%)$.
Table 9: Causes of Perinatal death in babies of PE and HELLP patients.

\begin{tabular}{|lll|}
\hline Cause of death & $\begin{array}{l}\text { PE } \\
(\text { no. of pts) }\end{array}$ & $\begin{array}{l}\text { HELLP } \\
\text { (no. of pts) }\end{array}$ \\
\hline Birth asphyxia & 2 & 2 \\
\hline Iud & 2 & 1 \\
\hline Sepsis & 1 & 1 \\
\hline $\begin{array}{l}\text { Respiratory distress } \\
\text { syndrome }\end{array}$ & 2 & 0 \\
\hline Ventilator dependency & 1 & 0 \\
\hline Pneumonia & 1 & 5 \\
\hline $\begin{array}{l}\text { Bronchopulmonary } \\
\text { dysplasia }\end{array}$ & 1 & 0 \\
\hline
\end{tabular}

Comparison of all variables and p value

Statistically significant differences were observed in lab values such as low $\mathrm{Hb}$, raised AST, ALT and LDH in HELLP syndrome, $\mathrm{p}$ value 0.000 .

Table 10: Comparison of variables studied in PE and HELLP patients.

\begin{tabular}{|lllll|}
\hline $\begin{array}{l}\text { Variables/ } \\
\text { mean } \\
\text { value }\end{array}$ & PE & HELLP & t value & p value \\
\hline Age & $\begin{array}{l}27.16 \pm \\
4.91\end{array}$ & $27.53 \pm 5.60$ & 0.3684 & 0.7133 \\
\hline SBP & $\begin{array}{l}153.16 \pm \\
12.59\end{array}$ & $153.85 \pm 14.28$ & 0.2688 & 0.7886 \\
\hline DBP & $\begin{array}{l}101.79 \pm \\
10.13\end{array}$ & $98.36 \pm 8.39$ & 1.9339 & 0.0557 \\
\hline Hb & $\begin{array}{l}9.07 \pm \\
0.97\end{array}$ & $6.40 \pm 1.20$ & 12.8328 & $0.000^{*}$ \\
\hline AST & $\begin{array}{l}28.65 \pm \\
6.03\end{array}$ & $166.67 \pm 93.12$ & 10.9691 & $0.000^{*}$ \\
\hline ALT & $\begin{array}{l}29.02 \pm \\
5.01\end{array}$ & $166.12 \pm 90.24$ & 11.25 & $0.000^{*}$ \\
\hline LDH & $\begin{array}{l}336.89 \pm \\
101.23\end{array}$ & $755.87 \pm 85.14$ & 23.491 & $0.000^{*}$ \\
\hline BU & $\begin{array}{l}28.12 \pm \\
11.65\end{array}$ & $28.71 \pm 9.01$ & 0.2971 & 0.7670 \\
\hline Uric acid & $\begin{array}{l}4.58 \pm \\
0.79\end{array}$ & $5.04 \pm 1.54$ & 1.9710 & 0.0513 \\
\hline $\begin{array}{l}\text { Baby } \\
\text { weight }\end{array}$ & $\begin{array}{l}2.00 \pm \\
0.74\end{array}$ & $1.76 \pm 0.84$ & 1.5899 & 0.1148 \\
\hline APGAR & $\begin{array}{l}6.12 \pm \\
1.97\end{array}$ & $6.04 \pm 2.12$ & 0.2050 & 0.8380 \\
\hline $\begin{array}{l}\text { Duration of } \\
\text { stay -NICU }\end{array}$ & $\begin{array}{l}3.03 \pm \\
1.01\end{array}$ & $4.07 \pm 1.21$ & 4.8935 & $0.000^{*}$ \\
\hline $\begin{array}{l}\text { Duration of } \\
\text { stay -ICU }\end{array}$ & $\begin{array}{l}3.14 \pm \\
2.1\end{array}$ & $4.73 \pm 1.21$ & 4.8653 & $0.000^{*}$ \\
\hline
\end{tabular}

\section{DISCUSSION}

\section{Demography}

In the present study, mean age of patients in both the groups was 27 years. Frequency of preeclampsia and HELLP did not vary according to gravida status of the 
woman, $30.9 \%$ were primigravida and $69.1 \%$ were multigravida.

The gestational age in HELLP syndrome was 36.77 weeks and in preeclampsia 35.83 weeks. Tandon et al, 2016 also observed preeclampsia at mean of 36.4 weeks and HELLP at mean 35.3 weeks. ${ }^{5}$ Preterm delivery $<34$ weeks was observed by Yildrim et al and Turgut et al. ${ }^{6},{ }^{7}$

\section{Maternal outcome}

In the present study, mean systolic BP was $153 \mathrm{mmHg}$ and $154 \mathrm{mmHg}$ and diastolic BP was $102 \mathrm{mmHg}$ and 98 $\mathrm{mmHg}$ in preeclampsia and HELLP groups respectively.

Biochemical parameters were significantly deranged ( $\mathrm{P}$ value 0.000-highly significant) in HELLP group. Study by Tandon et al also concluded the same. ${ }^{5}$

Headache was the most frequently recorded symptom in the present study with similar observations by Yildrim et al and Turgut et al. ${ }^{6,7}$

In the present study, frequency of vaginal deliveries was $52.72 \%$ and $81.81 \%$ in preeclampsia and HELLP groups respectively. Shafika Banoo et al, 2007 reported similar trend towards vaginal delivery in HELLP syndrome$60 \%{ }^{8}$ Other studies observed higher incidence of LSCS Yildrim et al (preeclampsia 68.3\%, HELLP 76.5\%), Turgut et al (preeclampsia 71.3\%, HELLP 81.1\%). ${ }^{6,7}$ Bang et al reported $65 \%$ vaginal delivery rate in HELLP syndrome patients. $^{9}$

Frequency of eclampsia was higher in HELLP group as compared to preeclampsia $(18.18 \%$ vs $9.01 \%)$ also observed by - Sep S. et al - (13\% vs 3\%), Pampus et al$(9.8 \%$ vs $3.9 \%) .^{10,11}$

In the present study, abruption was the most common maternal complication in both the groups with higher frequency in HELLP group- $12.7 \%$ vs $5.45 \%$. Similar incidence was observed by Tandon et al- $12.72 \%$ vs $2.09 \% .^{5}$ The overall incidence of complications was more in HELLP syndrome - $40 \%$ than in preeclampsia group $14.55 \%$. These findings are in accordance with all of the studies compared with Yildrim et al. ${ }^{6}$

39 patients $(70.9 \%)$ of HELLP needed transfusion of blood or blood products. Only 5 patients $(9.09 \%)$ in preeclampsia group needed blood transfusion. Maged et al reported need of blood transfusion as $84.3 \%$ in patients with eclampsia and HELLP syndrome and $42.5 \%$ in patients with HELLP syndrome. ${ }^{12}$

$34.55 \%$ patients were admitted to ICU in HELLP group while only $9.1 \%$ in preeclampsia group needed ICU. In 2016, Bedir et al observed that 34 out of 151 patients $(22.51 \%)$ of HELLP syndrome needed ICU care. ${ }^{13}$ Maternal mortality was $5.45 \%$ vs $1.8 \%$ in HELLP and preeclampsia groups. Kota et al, 2017 reported $6.66 \%$ maternal mortality in patients with HELLP syndrome. ${ }^{14}$ Kongwattanakul et al observed $2.6 \%$ intrapartum maternal mortality rate in preeclampsia patients and $6.4 \%$ in patients with severe features and HELLP syndrome. ${ }^{15}$ Tandon et al 2016 reported comparable low incidence of maternal mortality in preeclampsia group $-0.9 \%$, but the incidence of mortality in HELLP syndrome group was high $(18.18 \%) .^{5}$

\section{Perinatal outcome}

Marginally low birth weight was seen in HELLP than in preeclampsia group $-1.76 \mathrm{~kg}$ vs $2 \mathrm{~kg}$. The study result was comparable to that by Tandon et al $-1.8 \mathrm{~kg}$ vs $2.47 \mathrm{~kg} .^{5}$ Low birth weight with a mean of $1.8 \mathrm{~kg}$ in HELLP group as compared to $2.7 \mathrm{~kg}$ in preeclampsia group was also observed in study in 2018 by Kongwattanakul et al. ${ }^{15}$ ARDS was the most common complication, $29.09 \%$ vs $12.72 \%$ in HELLP and preeclampsia groups. Frequency of ARDS was also higher in HELLP than in preeclampsia in study by Turgut et al, $2010-13.3 \%$ vs $9.1 \%{ }^{7}$ IUGR was more common in preeclampsia than in HELLP (12.72\% vs $7.27 \%$ ); 2 other studies observed similar trend Yildrim et al $(53.4 \%$ vs $50.8 \%)$ and Turgut et al (25.2\% vs 0). ${ }^{6,7}$ Admission rate to NICU was marginally higher in HELLP compared to preeclampsia $(32.72 \%$ vs $30.9 \%)$. $36.6 \%$ neonates were admitted to NICU in a study conducted by Bang et al. ${ }^{9}$ Neonatal deaths were $15.38 \%$ in HELLP group and $13.2 \%$ in preeclampsia group. Bang et al reported $8.3 \%$ of early neonatal deaths. ${ }^{9}$ Perinatal mortality in HELLP syndrome patients was $20.5 \%$ in a study by Ascoglu et al and $40.5 \%$ in study by Chawla et al. ${ }^{16,17}$

\section{CONCLUSION}

HELLP syndrome and preeclampsia, both, have a derailing impact on the mother and fetus. This study supports the idea that HELLP syndrome is associated with increased maternal morbidity and mortality as compared to preeclampsia. Neonatal outcomes appear to be influenced; only marginally, by HELLP syndrome, nevertheless, their incidence is more than in preeclampsia. Aggressive treatment for pregnant women appears to decrease the maternal mortality rate. Also, this observation allows the clinician to be more attentive to clinical and biochemical disturbances in patients that would lead to an early diagnosis of HELLP syndrome and the cascade of complications can thus be prevented.

The following measures may be suggested on the basis of this study to reduce adverse outcomes: Timely identification of high risk cases and early diagnosis of HELLP syndrome patients from amongst the preeclampsia cohort should be done. Management and delivery of HELLP syndrome mothers and care of newborns should be undertaken at tertiary health centres by highly trained personnel. Adult and neonatal intensive care units, 24 hour blood bank should be available. Last but not the least, aggressive multispecialty management 
by obstetrician, paediatrician, physician and anaesthetist is essential to save, both, the mother and the child.

\section{ACKNOWLEDGMENTS}

Authors would like to thank the unit heads (Dr. Rita Ranjan, Dr. VK Kadam) after whose due permission patients were recruited are hereby acknowledged for granting permission. Dr. Madhva Prasad is deeply acknowledged for his support, guidance and encouragement to the authors.

Funding: No funding sources Conflict of interest: None declared

Ethical approval: The study was approved by the Institutional Ethics Committee

\section{REFERENCES}

1. Sibai BM, Taslimi MM, El-Nazer A, Amon E, Mabie BC, Ryan GM. Maternal-perinatal outcome associated with the syndrome of hemolysis, elevated liver enzymes, and low platelets in severe preeclampsia-eclampsia. Am J Obstet Gynecol. 1986;155(3):501-8.

2. Sibai BM, Ramadan MK, Usta I, Salama M, Mercer BM, Friedman SA. Maternal morbidity and mortality in 442 pregnancies with hemolysis, elevated liver enzymes, and low platelets (HELLP syndrome). Am J Obstet Gynecol. 1993;169(4):1000-6.

3. Weinstein L. Syndrome of hemolysis, elevated liver enzymes, and low platelet count: A severe consequence of hypertension in pregnancy. Am $\mathrm{J}$ Obstet Gynecol. 1982;193(3 Pt 1):859; discussion 860.

4. Martin J, Rinehart BK, May WL, et al. The spectrum of severe preeclampsia: Comparative analysis by HELLP (hemolysis, elevated liver enzyme levels, and low platelet count) syndrome classification. In: Americ J Obstetr Gynecol. 1999;180(6 Pt 1):137384.

5. Tandon A, Chaudhari P, Gupta V, Ramola M. Fetomaternal outcome in patients with HELLP and partial HELLP syndrome: a prospective 10 year study in Shri Guru Ram Rai Institute of Medical and Health Sciences, Uttarakhand, India. Int J Reprod Contraception, Obstet Gynecol. 2016;5(9):3066-71.

6. Yildirim G, Gungorduk K, Aslan H, Gul A, Bayraktar M, Ceylan Y. Comparison of perinatal and maternal outcomes of severe preeclampsia, eclampsia, and HELLP syndrome. J Turkish Ger Gynecol Assoc. 2011;12(2):90-6.

7. Turgut A, Demirci O, Demirci E, Uludoğan M. Comparison of maternal and neonatal outcomes in women with HELLP syndrome and women with severe preeclampsia without HELLP syndrome. J Prenat Med. 2010;4(3):51-8.

8. Banoo S, Makhdoomi TA, Mir S, Malik JA. Incidence of Help syndrome in severe Pregnancy Induced Hypertension and its impact on maternal and fetal outcome. JK Pract. 2007;14(2):92-4.

9. Bang N, Satia M, Poonia S. Obstetric and neonatal outcome in pregnancies complicated by hemolysis elevated liver enzymes low platelet count syndrome at a tertiary care centre in India. Int $\mathbf{J}$ Reprod Contraception, Obstet Gynecol. 2016;2407-12.

10. Sep S, Verbeek J, Koek G, Smits L, Spaanderman M, Peeters L. Clinical differences between early-onset HELLP syndrome and early-onset preeclampsia during pregnancy and at least 6 months postpartum. Am J Obstet Gynecol. 2010;202(3):271.e1-5.

11. Van Pampus MG, Wolf H, Westenberg SM, Van Der Post JAM, Bonsel GJ, Treffers PE. Maternal and perinatal outcome after expectant management of the HELLP syndrome compared with pre-eclampsia without HELLP syndrome. Eur J Obstet Gynecol Reprod Biol. 1998;76(1):31-6.

12. Maged AM, Elsherief A, Hassan H, et al. Maternal, fetal, and neonatal outcomes among different types of hypertensive disorders associating pregnancy needing intensive care management. Journal of Maternal-Fetal and Neonatal Medicine. 2018;9:1-8.

13. Bedir Z, Ahiskalioglu A, Esenkaya, et al. HELLP syndrome is still a serious, life-Threatening complication of pregnancy: Admission of 34 women to an eastern Turkish intensive care unit. Clin Exp Obstet Gynecol. 2016;43(6):795-9.

14. Kota LN, Garikapati K, Kodey PD, K. B. G. Study on HELLP syndrome - maternal and perinatal outcome. Int J Reprod Contraception, Obstet Gynecol. 2017;6(2):714-9.

15. Kongwattanakul K, Saksiriwuttho P, Chaiyarach S, Thepsuthammarat K. Incidence, characteristics, maternal complications, and perinatal outcomes associated with preeclampsia with severe features and hellp syndrome. Int $\mathrm{J}$ Womens Health. 2018;10:371-7.

16. Ascoglu $\mathrm{O}$, Güngördük K, Yildirim G, Aslan H, Günay T. Maternal and perinatal outcomes of eclampsia with and without HELLP syndrome in a teaching hospital in western Turkey. J Obstet Gynaecol (Lahore). 2014;34:326-31.

17. Chawla S, Marwaha A, Agarwal R. HELLP or Help: A Real Challenge. J Obstet Gynecol India. 2015;65(3)172-5.

Cite this article as: Madge H, Seth S. Maternal and perinatal outcome in patients of preeclampsia with and without HELLP syndrome. Int J Reprod Contracept Obstet Gynecol 2019;8:2065-70. 